\title{
PESANTREN DAN BUDAYA KEPENULISAN
}

\author{
Yahya Aziz \\ IAIN Sunan Ampel Surabaya \\ Email: yahya.aziz@yahoo.co.id
}

\section{Abstract}

This study aims to describe and analyze the implementation of Practical Journalism as media development potential of students in boarding school student Hashim Ash'ari Yogyakarta. The results showed: (1) Practical Journalism schools are activities that are categorized as semi-autonomous schools curriculum that aims to develop the potential of students of authorship in the media. Learning methods used are lecture-dialogue-assignment. Strategy adopted there are three things: provoke the onset of motivation to write the first and second introducing practical theories (which are directly related to the practice), and a third practice and actualization of the work. (2) efforts to develop the potential of authorship through Practical Journalism can be said to succeed termuatnya reflected in the writings of the students in various media, whether it is national or local scale. With this success, indirectly from the boarding schools have done improfisasi methodology and combines the elements of job-related skills (vocational) with scientific development.

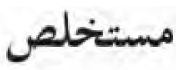

تبحث هذه المقالة إلى وصف وتحليل تنفيذ الصحافة العملية بوصفها إمكانات تطوير وسائل الإعالام للطلاب في المعهد الإسالمي الطابلي هاشم الأشعري يوجياكارتا. وأظهرت النتائج : (1) عملي كليات الصحافة والأنشطة التي يتم تصنيفها على أها مناهج المعهد شبه المستقلة والتي تمف إلى تطوير قدرات الطلاب في التأليف في وسائل الإعلام. أساليب التعلم المستخدمة هي محاضرة للحوار الاحالة. اعتملت استراتيجية وهناك ثالثة أشياء : استفزاز ظهور الدافع لكتابة الأولى والثانية إدخال النظريات العملية (والتي ترتبط مباشرة إلى الممارسة)، وممارسة الثالث والادراك للعمل. (2) يمكن أن 


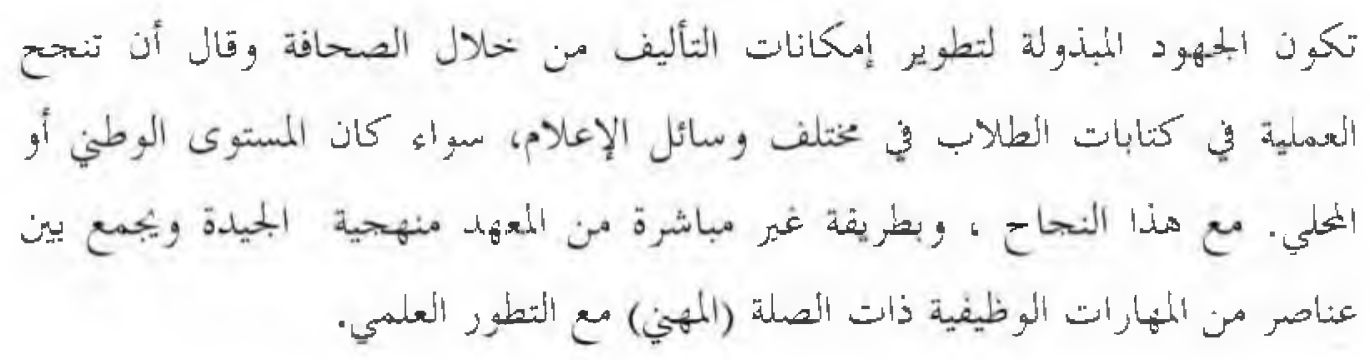

Keywords: Budaya Kepenulisan, Pesantren, Santri, Jurnalistik Praktis

\section{A. Pendahuluan}

Pesantren selama ini dikenal sebagai lembaga pendidikan tradisional Islam. Namun demikian, sesungguhnya pesantren turut memainkan peranan yang cukup signifikan dalam membina dan mengembangkan SDM untuk menggapai keunggulan (excellence). Sebagai lembaga pendidikan Islam pondok pesantren sepanjang sejarahnya telah berperan besar dalam upaya-upaya meningkatkan kecerdasan dan martabat manusia. ${ }^{1}$

Apabila dirunut ke belakang, eksistensi pesantren telah mendapat pengakuan masyarakat sejak kolonialisme membelenggu bangsa Indonesia. Betapa tidak, pesantren ikut serta terlibat dalam usaha pencerdasan kehidupan bangsa bukan saja dari aspek moralitas, tetapi juga dalam kiprahnya menyelenggarakan pendidikan ilmu-ilmu ke(agama)an Islam. Pesantren telah berjasa besar dalam melahirkan ulama, tokoh masyarakat, guru agama, bahkan tokoh-tokoh pergerakan sosial-politik Indonesia.

Fungsi pesantren tersebut hingga kini tetap terjaga dengan baik, bahkan sebagian telah mengembangkan fungsi dan perannya sebagai pusat pengembangan masyarakat. ${ }^{2}$ Pesantren pun dituntut untuk menciptakan generasi muslim yang independen dan memiliki life skill yang dapat diandalkan. Hal inilah yang dibutuhkan dalam menghadapi era globalisasi. Sebab, persaingan di era globalisasi hanya dimenangkan oleh manusia yang berkualitas. ${ }^{3}$

1 M. Fajrul Falakh, Pesantren Masa Depan: Wacana Pemberdayaan dan Transformasi Pesantren, (Bandung: Pustaka Hidayah, 1999), hal. 134.

2 Said Agil Siraj, et.al, Pesantren Masa Depan, (Bandung: Pustaka Hidayah, 1999), hal. 140.

3 Zulkifli, Sufi Pesantren, (Yogyakarta: LKIS, 2002), hal. 160. 
Pada konteks ini peran pesantren tentu harus ditingkatkan, sebab tuntutan globalisasi mustahil dihindari. Falakh menegaskan bahwa keunggulan SDM yang ingin dicapai pondok pesantren adalah terwujudnya generasi muda yang berkualitas tidak hanya pada aspek kognitif, tetapi juga pada aspek afektif dan psikomotorik. ${ }^{4}$ Berkaitan dengan hal tersebut, mengatakan bahwa peserta didik (santri) harus dibekali dengan berbagai kemampuan sesuai dengan tuntutan zaman guna menjawab tantangan globalisasi, berkontribusi pada pembangunan masyarakat dan kesejahteraan sosial, lentur, dan adaptif terhadap berbagai perubahan. ${ }^{5}$

Namun demikian, mereposisi peranan pesantren tersebut tidaklah gampang. Permasalahan seputar pengembangan model pendidikan pesantren dalam hubungannya dengan peningkatan kualitas sumber daya manusia (human resources) merupakan isu aktual dalam arus perbincangan kepesantrenan kontemporer. Maraknya perbincangan mengenai isu tersebut tidak bisa dilepaskan dari realitas empirik keberadaan pesantren dewasa ini kurang mampu mengoptimalisasi potensi yang dimilikinya.

Setidaknya terdapat dua potensi besar yang dimiliki pesantren yaitu potensi pendidikan dan pengembangan masyarakat. Khusus dalam bidang pendidikan, misalnya, pesantren dapat dikatakan kalah bersaing dalam menawarkan suatu model pendidikan kompetitif yang mampu melahirkan out put (santri) yang memiliki kompetensi dalam penguasaan ilmu sekaligus skill sehingga dapat menjadi bekal terjun ke dalam kehidupan sosial yang terus mengalami percepatan perubahan akibat modernisasi yang ditopang kecangihan sains dan teknologi. Kegagalan pendidikan pesantren dalam melahirkan sumber daya santri yang memiliki kecakapan dalam bidang ilmu-ilmu keislaman dan penguasaan life skill secara sinergis berimplikasi terhadap kemacetan potensi pesantren kapasitasnya sebagai salah satu agen perubahan sosial (agents of social change) dalam berpartisipasi mendukung proses transformasi sosial bangsa. ${ }^{6}$

Di kalangan pesantren sendiri, setidaknya sejak dasawarsa terakhir telah muncul kesadaran untuk mengambil langkah-langkah tertentu guna meningkatkan kualitas SDM yang mampu menjawab tantangan dan kebutuhan transformasi sosial

4 M. Fajrul Falakh, Pesantren Masa Depan..., hal. 48.

5 Martin Van Brunessen, Kitab Kuning Pesantren dan Tarikat: Tradisi-Tradisi Islam di Indonesia, (Bandung: Mizan, 1999), hal. 67.

- Abdurrahman Mas'ud, "Pesantren dan Walisongo: Sebuah Interaksi dalam Dunia Pendidikan” dalam M. Darori Amin (ed.), Islam dan Kebudayaan Jawa, (Yogyakarta: Gama Media, 2000), hal. 224. 
(pembangunan). Dari sinilah timbul berbagai model pengembangan SDM, baik dalam bentuk perubahan kurikulum pesantren yang lebih berorientasi kepada kekinian, dalam bentuk kelembagaan baru, atau sekolah-sekolah umum di lingkungan pesantren. ${ }^{7}$

Bahkan di beberapa pesantren telah melakukan reorientasi pendidikan yang lebih menekankan life skill dengan memperkenalkan pelatihan-pelatihan keterampilan (vocational) dalam sistem pendidikannya. Pesantren Tebuireng dan Rejoso sejak dekade 1950-an dan awal 1960-an, sebagaimana diungkap Madjid, ${ }^{8}$ telah mengarahkan santrinya untuk terlibat dalam kegiatan vocational bidang pertanian dan perdagangan. Begitu juga pesantren Gontor, Denanyar, Tambakberas, dan Tegalrejo telah mengembangkan koperasi.

Kendati demikian, sejauh ini jarang sekali pesantren yang benar-benar memperhatikan secara serius improvisasi kurikulum mengenai langkah pengenalan keluar secara lebih luas terhadap keilmuan yang diajarkan. Padahal menurut Zuhri, segala potensi yang ada, khususnya di bidang transmisi keilmuan klasik, jika tidak dikembangkan dan didukung dengan improvisasi metodologi hanya akan menghadirkan pemupukan keilmuan. ${ }^{9}$

Berdasar atas fenomena tersebut, Pesantren Mahasiswa Hasyim Asy'ari Yogyakarta tampil sebagai pesantren yang telah melakukan improvisasi kurikulum dan metodologi pendidikan. Berbeda dengan sejumlah pesantren lain di Yogyakarta seperti Al-Munawwir, Al-Muhsin, Ma'had Ali, dan Luqmaniyyah yang mengkhususkan kurikulumnya bagi keilmuan klasik, Pesantren Mahasiswa Hasyim Asy'ari telah mencoba melakukan langkah improvisasi metodologi, yaitu memperluas penyebaran wacana dan keilmuan melalui tulisan, lewat program Jurnalistik Praktis.

Pesantren Mahasiswa Hasyim Asy'ari memiliki visi-misi membimbing dan mencerdaskan santrinya agar siap menyongsong masa depan melalui program kepenulisan. Kegiatan itu merupakan gabungan antara unsur vocational dan pengembangan keilmuan. Para santri di pesantren tersebut dibimbing untuk menjadi penulis yang siap menghadapi masa depan, berdarma dan berjuang melalui ilmu yang dimilikinya.

7 Nurcholis Madjid, Bilik-bilik Pesantren: Sebuah Potret Perjalanan, Jakarta: Paramadina, 199), hal. xv.

8 Ibid., hal. Xviii.

9 Ar. Wahyoetomo, Perguruan Tinggi Pesantren Alternatif Masa Depan, (Jakarta: Gema Indonesia Press, 1990), hal. 201. 
Para santri dibebaskan menempuh jalan yang berbeda-beda sesuai kompetensi dan kemampuan masing-masing dalam kerangka kepenulisan dengan idealisasi masuk ke media massa dan dunia perbukuan. Mereka bisa memilih cerpen, opini, puisi, artikel, atau yang lainnya.

Pengarahan visi-misi melalui program semacam Jurnalistik Praktis paling tidak bisa mengandung tiga kelebihan. Pertama, improvisasi metodologi bagi keilmuan santri; kedua, aktualisasi keterampilan menulis (vocational); dan ketiga, penanaman prinsip belajar untuk menjadi (learning to know) atau belajar untuk memperoleh pengetahuan guna melakukan pembelajaran selanjutnya dan (learning to do). Dengan kata lain, belajar untuk memiliki kompetensi dasar dalam hubungan dengan tim kerja yang berbeda-beda. ${ }^{10}$

Program Jurnalistik Praktis itu sendiri merupakan kegiatan yang secara khusus membimbing santri menuju profesionalisme kepenulisan. Artinya, program ini hendak mengembangkan potensi kepenulisan para santrinya dalam bidang kepenulisan yang menitikberatkan pada aspek praktik daripada teori. Karena itu, perlu dilihat, pertama, bagaimana pelaksanaan program Jurnalistik Praktis di Pesantren Mahasiswa Hasyim Asy'ari; dan, kedua, apa hasil dan manfaat usaha pengembangan potensi kepenulisan santri melalui program Jurnalistik Praktis tersebut.

\section{B. Pembiasaan Budaya Menulis}

Pesantren Mahasiswa Hasyim Asy'ari dirintis oleh K.H Zainal Arifin Thoha pada tahun 1995. Untuk membiasakan budaya kepenulisan diagendakan Program Jurnalistik Praktis. Jurnalistik Praktis adalah suatu kegiatan yang masuk dalam kurikulum semi otonom pesantren Hasyim Asy'ari yang secara khusus berusaha mengarahkan para santri dalam bidang kepenulisan. Kurikulum semi otonom pesantren adalah kurikulum pesantren yang di dalam pelaksanaannya mengambil waktu dan jam tersendiri, lepas dari jadwal pelajaran yang telah ditentukan. ${ }^{11}$

Istilah ini digunakan sebagai langkah pembedaan dengan kegiatan ekstra yang pada umumnya tidak bersifat dominan di dalam suatu lembaga. Kurikulum ini pada dasarnya hampir sama dengan "kegiatan ekstra", tetapi kurikulum ini lebih

10 Khoiruddin Bashori, Problem Psikologis Kaum Santri: Risiko Insekuritas Kelekatan, (Yogyakarta: FKBA, 2003), hal. 70-71.

11 Wawancara dengan Muhammadun AS, 12 April 2007. 
dominan dari kegiatan lain karena menjadi kegiatan inti pesantren, terbukti dengan adanya kegiatatan-kegiatan lain yang sebagian besar mengarah/ mendukung pada kompetensi menulis. Padahal yang menjadi wadah mengembangkan potensi menulis adalah "Jurnalistik Praktis".

Jurnalistik Praktis oleh pihak pesantren diartikan sebagai latihan kepenulisan yang dilaksanakan untuk mengikuti isu-isu aktual di media massa (bukan jurnalistik berita/reportase) dalam bentuk opini, resensi buku, puisi, essai sastra, cerpen, novel yang menitikberatkan pada aspek praktik dalam pelaksanaannya. ${ }^{12}$

Jurnalistik Praktis dari pihak pesantren juga mempunyai tujuan tertentu. Seara garis besar tujuan tersebut dibagi kedalam tiga bagian; Pertama, dengan diadakannya pelatihan Jurnalistik Praktis diharapkan para santri bisa ikut berpartisipasi dalam kegiatan pengembangan keilmuan melalui media massa dengan menggunakan cara atau jalan yang berbeda-beda. Kemampuan, bakat dan minat para santri diharapkan bisa diarahkan menuju pengapresiasian pendapat dan keinginan terhadap sasaran yang lebih luas, yaitu khalayak.

Para santri bisa menyampaikan apa yang diyakini sebagai kebenaran (dalam syariat Islam) melalui berbagai media, bisa lewat artikel, cerpen, puisi, buku, novel dan sebagainya. Para santri yang berlatar belakang dan pendidikan berbeda-beda diharapkan bisa melahirkan kontribusi yang bermanfaat melalui tulisan, sesuai dengan kompetensi dan bidang masing-masing. Santri mahasiswa yang di Fakultas Tarbiyah dapat menyampaikan kontribusinya tentang pendidikan, Fakultas Syariah tentang hukum, Fakultas Adab tentang kesusastraan Arab, Fakultas Ushuluddin tentang dasar-dasar agama, Fakultas Dakwah tentang alternatif pengembangan Islam melalui media massa.

Kedua, dengan Jurnalistik Praktis para santri bisa menjalani proses menuju hidup mandiri, karena pengasuh menyarankan agar semaksimal mungkin tidak menggantungkan orang tua, meskipun harus bersusah-susah dan kerja keras. Dengan termuatnya tulisan di media-media massa akan mendatangkan konsekuensi finansial, yaitu berupa honor. Dengan adanya konsekuensi tersebut, jika para santri telah mapan dalam dunia kepenulisan, bisa memprediksi kemampuannya dan peka terhadap momentum, maka untuk biaya hidup dan perkuliahan menjadi tidak masalah, artinya kemandirian telah tercapai dengan bekal keilmuan.

Bagi para santri yang belum begitu mapan dalam menulis, khususnya santri baru, dari pihak pesantren melalui lembaga milik pesantren yang berupa penerbit

12 Wawancara dengan Ach. Mukhlis AR, 25 April 2007. 
"Kutub" memberikan peluang melalui berjualan buku secara asongan yang oleh pengasuh dianggap sebagai "alternatif jangka pendek" yang berfungsi menopang kehidupan menuju "tujuan jangka panjang" yang masih dilalui dalam proses, yaitu kemapanan dalam "menulis". Inilah yang sempat dipancangkan oleh Gus Zainal dalam sebuah kegiatan "Membangun Etos Kerja dan Kepenulisan" pada 12 Maret 2007.

Ketiga, dengan Jurnalistik Praktis diharapkan dapat membimbing dan mengarahkan para santri di dalam kebiasaan membaca. Hal ini sangat prinsip di dalam dunia kepenulisan, karena dalam menulis yang parameternya adalah selera khalayak melalui tim redaktur masing-masing media massa diperlukan kepekaan dan wawasan yang luas. Hal ini bisa dicapai jika santri benar-benar rajin membaca dan belajar, baik itu dari literatur-literatur yang berwujud wacana ataupun realitas yang ada. Dengan demikian, membaca dan belajar kepada realitas menjadi sebuah kebutuhan, dan kebutuhan itu akan dicari oleh pihak yang membutuhkan selama dia hidup.

Berdasarkan prinsip inilah, kemudian prinsip learning to know (belajar untuk memperoleh pengetahuan dan melaksanakan pembelajaran selanjutnya) dan learning to do (belajar untuk memiliki kompetensi dasar dalam hubungannya dengan tim kerja yang berbeda) menjadi sebuah prinsip. Bila orang telah mempunyai prinsip yang jelas, maka kecenderungan untuk bertindak positif lebih besar. Jadi dari sisi lain kebiasaan menulis dapat membimbing menuju pendewasaan mental.

\section{Implementasi Jurnalistik Praktis}

Pelaksanaan Jurnalistik Praktis secara garis besar ditujukan kepada dua sasaran, yaitu "ke dalam" yaitu para santri dan "ke luar" yaitu pihak lain yang berada di luar pesantren. Adapun fokus utamanya adalah pelatihan kedalam, baru setelah dianggap mampu dan sukses akan dilanjutkan dengan pelatihan ke luar oleh para santri yang telah dianggap berhasil pada pelatihan atau diklat di dalam.

\section{Diklat ke Dalam}

Pada dasarnya diklat ke dalam adalah merupakan inti dari tujuan pesantren, yaitu membimbing para santrinya menjadi penulis muslim yang beriman dan bertakwa. Karena sasaran utamanya membimbing para santri, maka orientasi awal yang harus dikejar adalah kompetensi untuk para santri itu sendiri. Mengenai yang keluar bisa dilaksanakan sambil berjalan mengikuti prosesnya.

Karena Pesantren Mahasiswa Hasyim Asy'ari merupakan pesantren baru, yang baru didirikan pada sekitar tahun 2003 maka sangatlah wajar bila dalam menetapkan 
kurikulumnya juga perlu proses dan penyesuaian dengan situasi atau kondisi para santri. Baru sekitar tahun 2004-lah kurikulum di pesantren tersebut mulai mapan dan terorganisir dengan baik. Diklat Jurnalistik Praktis sendiri baru dilaksanakan mulai awal tahun 2007 dengan pemandu langsung dari pengasuh, yaitu K.H. Zainal Arifin Thoha. ${ }^{13}$

Diklat dilaksanakan seminggu sekali, yaitu pada tiap Sabtu sore sekitar pukul 15. 30 WIB sampai masuk waktu maghrib. Tujuan dari pelaksanaan diklat tersebut adalah untuk memancing motivasi para santri dalam bidang kepenulisan dan mengarahkannya menuju aktualisasi karya. Untuk karya yang meski ditekuni diserahkan kepada masing-masing santri, meskipun di dalam pelatihan tersebut minimal harus membuat tugas dengan jumlah karya yang ditentukan pembimbing. Penugasan tersebut selain dijadikan sebagai langkah aktualisasi karya dan strategi dari Jurnalistik Praktis itu sendiri juga sebagai sarana untuk menjajaki sejauh mana kecenderungan dan kompetensi dari masing-masing santri. Dengan begitu untuk mengarahkannya menjadi lebih mudah.

Secara garis besar metode yang digunakan dalam diklat tersebut meliputi tiga cara, yaitu pertama memancing motivasi santri, kedua pengenalan teori-teori praktis dalam kepenulisan, dan ketiga praktik menulis sebagai aktualisasi karya. Ketiga hal itu akan dibahas di dalam kajian berikutnya, yaitu pada Metode dan Strategi Pembelajaran Jurnalistik Praktis.

Untuk lebih mengoptimalkan pelaksanaan bimbingan, pada akhirnya sebagai tindak lanjut platihan, ditunjuklah beberapa santri senior yang telah cukup mapan di dalam menulis untuk membimbing para santri baru dalam menempuh proses kepenulisan. Pembimbingan ini oleh pihak pesantren dikenal dengan istilah "Sistem Pendampingan".

Untuk mendukung para santri di dalam memupuk ketajaman analisis, khususnya mengenai permasalahan dan isu-isu aktual di sekitar media massa, dalam kurikulum pesantren juga dibentuk sebuah kajian yang bermaksud mendukung kegiatan Jurnalistik Praktis dengan nama "Kajian Editorial". Kajian ini dikoordinir oleh Gugun Al Gulyani mahasiswa Fakultas Syariah UIN Sunan Kalijaga.

Dalam pelaksanaan diklat, khususnya yang berorientasi ke dalam dapat dikatakan telah berhasil, terbukti dengan termuatnya tulisan para santri di berbagai media massa, baik itu media massa yang berskala lokal seperti Solo Pos, Bernas, Kedaulatan Rakyat, Suara Merdeka, Suara Karya, Surabya Pos, Wawasan, Seputar

13 Wawancara dengan Muhammadun AS, 12 April 2007. 
Indonesia, Bali Pos, Kompas Jatim dan Kompas Jogja maupun yang berskala nasional seperti Kompas, Jawa Pos, Tempo, Republika, Media Indonesia dan Bisnis. (sample data terlampir). Jumlah santri ada 70 orang, yang telah termuat tulisannya ada 55 orang. Jadi porsentase keberhasilan sekitar $70 \%$. Adapun sebagian data tersebut adalah sebagai berikut:

\begin{tabular}{|c|c|c|c|c|}
\hline $\mathrm{N}_{\mathrm{o}}$ & Nama santri & Media massa & Jenis tulisan & $\begin{array}{c}\text { Berapial kali } \\
\text { dimuat }\end{array}$ \\
\hline \multirow[t]{10}{*}{1} & Mulamadurn A.S. & Kompas & Opini & 2 kali \\
\hline & & Kompas lokal & Opini & 5 kali \\
\hline & & Jawa Pos & Opini, resensi & $3 \mathrm{kali}, 5 \mathrm{kali}$ \\
\hline & & Tempo & Resensi & 3 kali \\
\hline & & Republiki & Opini, resensi & $1 \mathrm{kali}_{1} 3 \mathrm{kuli}$ \\
\hline & & Bisnis & Resensi & 2 kali \\
\hline & & Media Indonesia & Resensi & 1 kali \\
\hline & & Solo Pos & Opini, resensis & 2 kali, 2 kali \\
\hline & & Kedaulatan Rakyat & Opini, resensi & 2 kali, 1 kali \\
\hline & & Seputar Indonesia & Resensi & $3 \mathrm{kali}$ \\
\hline \multirow[t]{6}{*}{2} & Ahmad Muchlish & Kompas lokal & Essai sastra & 3 lali \\
\hline & & lawa Pos & Essai sastra, puisi & 2 kalli, 5 kali \\
\hline & & Solo Pos & Puisi & 4 kali \\
\hline & & Bali Pos & Puisi & 2kali \\
\hline & & Kedaaulatan Rukyat & $\begin{array}{l}\text { Essia sastra, puisi. } \\
\text { сетрел }\end{array}$ & $\begin{array}{l}2 \text { kali, } 7 \text { kali, } \\
3 \text { kali }\end{array}$ \\
\hline & & Minggu Pagi & Puisi & fo kali \\
\hline \multirow[t]{5}{*}{3} & Silman Rusydi & Kompas lokal & apini & $2 \mathrm{kali}$ \\
\hline & & Jawa Pos & Prokon Aktifis, puisi & 6 kali, 4 kali \\
\hline & & Kedaulatan Rakyat & Puisi & 5 kali \\
\hline & & Bemas & Puisi & $2 \mathrm{kali}$ \\
\hline & & Sepular Indonesla & Opini & 1 hali \\
\hline \multirow[t]{4}{*}{4} & Khaurul Anam & Jiwal Pos & Puisi & 4 kuli \\
\hline & & Kedaulatin Rakyat & Puisi & 4 kali \\
\hline & & Seputar Indonesia & Puisi & $3 \mathrm{kali}$ \\
\hline & & Berlods & Puisi & $1 \mathrm{kali}$ \\
\hline \multirow[t]{2}{*}{5} & Faauzi $A$. & Bernas & Opini & 3 hali \\
\hline & & Kedaulatun Rakyat & Opini & 1 kali \\
\hline 6 & Fazathu Rasyid & Kedaulatan Rakyat & Resernsi & i kali \\
\hline \multirow[t]{3}{*}{7} & Gugun aal Gulyani & Seputar Indonesia & Opint & 1 kali \\
\hline & & Bernas & Opini & 3 kali \\
\hline & & Kedaulatan Rakyat & Opini & 3 kali \\
\hline \multirow[t]{2}{*}{8} & Hasan A. & Sepulat Inddonesia & Resensi & 1 kali \\
\hline & & lawa Pos & Resensi & $1 \mathrm{kali}$ \\
\hline 9 & Luqman & Solo Pos & Opini & 1 kali \\
\hline 10 & Wahyudin & Bemas & Opini & 1 kali \\
\hline
\end{tabular}




\begin{tabular}{|l|l|l|l|l|}
\hline 11 & Mustain & Solo Pos & Resensi & 1 kali \\
\hline 12 & Mubib & Jawa Pos & Opini & 2 kali \\
\hline & & Solo Pos & Opini & 2 kali \\
\hline 13 & Alfiyan & Jawa Pos & Puisi & 2 kali \\
\hline 14 & Yusriyanto & Solo Pos & Opini & 1 kali \\
\hline 15 & Kurniawan & Solo Pos & Opini & 2 kali \\
\hline & & Bemas & Opini & 1 kali \\
\hline
\end{tabular}

\section{Diklat Ke Luar}

Diklat ke luar adalah pelatihan yang ditujukan kepada selain santri. Sasaran yang hendak dicapai dalam diklat keluar adalah para mahasiswa di universitasuniversitas terdekat seperti di UIN Sunan Kalijaga, UNY, UGM, UAD dan umum. Diklat dilaksanakan selama dua bulan dengan perincian delapan pertemuan atau seminggu sekali. Pelaksanaan diklat pada hari Minggu pukul 09.00 WIB di ruang aula Pesantren Mahasiswa Hasyim Asy'ari.

Diklat dipandu oleh K.H Zainal Arifin Thoha dibantu para santri senior yang telah dipercaya. Materi yang disajikan meliputi opini, artikel, essay sastra, cerpen, puisi, novel dan resensi buku yang dibahas dalam tujuh pertemuan. Adapun pertemuan terakhir (kedelapan) membahas semua materi yang telah disampaikan.

Sebelum diklat dilaksanakan, pihak pesantren membentuk tim khusus untuk diklat keluar. Adapun kepengurusannya diketuai oleh Agus Ariyanto, sekertaris dan bendahara oleh M Luthfi, publikasi oleh A. Muchlish A.R. dan perlengkapan oleh Purnama Adi Saputra.

Diklat pertama dilakukan pada bulan Februari sampai Maret 2007 Diklat berjalan pada putaran pertama dengan peserta sebanyak sepuluh orang, ditambah para santri yang mau mengikutinya. Namun untuk diklat berikutnya tidak berjalan, hal ini dikarenakan beberapa hal yang di antaranya kekurangkompakan dan koordinasi masing-masing tim di dalam melaksanakan proses pelatihan, baik itu menyangkut pemenuhan fasilitas, kebutuhan maupun metode yang menarik dan efektif bagi peserta di luar. ${ }^{14}$ Jadi secara umum untuk mengembangkan ke luar masih perlu proses dan kesiapan lebih matang lagi.

\section{Metode dan Strategi Pembelajaran Jurnalistik Praktis}

Metode yang digunakan di dalam pembelajaran Jurnalistik Praktis adalah ceramah, dialog dan penugasan (membuat karya). Ceramah dilakukan sebagai

14 Wawancara dengan Muhammadun AS, 12 April 2007. 
sarana transformasi materi dari pembimbing kepada peserta, forum dialog digunakan sebagai waktu bertanya-jawab dan membicarakan materi dan penugasan sebagai tindak lanjut dan aktualisasi teori yang telah disampaikan mengenai kepenulisan.

Dalam rangka mencapai efektifitas dan efisiensi proses pembelajaran diperlukan strategi dan langkah yang tepat. Dengan strategi tersebut pihak pesantren mengharapkan tujuan pelatihan dapat tercapai dengan optimal. Strategi yang diterapkan ada tiga langkah, yaitu pertama Peningkatan Motivasi sebagai Dasar Utama Pengembangan Potensi Kepenulisan di Pesantren Mahasiswa Hasyim Asy'ari, kedua Pengenalan Teori-teori Praktis dalam Pembelajaran Jurnalistik Praktis, dan ketiga Praktik Menulis dan Aktualisasi Karya.

\section{Peningkatan Motivasi sebagai Dasar Utama Pengembangan Potensi Kepenulisan}

Pihak pesantren berusaha menumbuhkan kecenderungan para santri di dalam mengembangkan dan terjun dalam dunia kepenulisan melalui tiga cara, yaitu pertama Bimbingan Kepenulisan, kedua Mendatangkan Para Tokoh yang Telah Sukses Menulis, dan ketiga Membangun Iklim Penulis.

\section{a. Bimbingan Kepenulisan}

Untuk membangun motivasi pada diri para santri pada proses kepenulisan, salah satu langkah yang dilakukan adalah melalui bimbingan kepenulisan atau diklat. Bimbingan kepenulisan dilakukan seminggu sekali, yaitu pada hari Sabtu sore, kira-kira pukul 15.30 WIB sampai masuknya waktu maghrib (adzan). Status bimbingan ini di dalam pesantren adalah sebagai kurikulum semi otonom, sebagaimana dijelaskan pengertiannya di depan. Diklat ini dilaksanakan sejak bulan Agustus tahun 2006.

Diklat dilaksanakan di Pesantren Mahasiswa hasyim Asy'ari di ruang aula/ pertemuan yang diikuti oleh para santri dan dibimbing langsung oleh K.H. Zainal Arifin Thoha sebagai pengasuh pesantren

Metode yang digunakan di dalam pelaksanaan diklat ini adalah ceramah, dialog dan penugasan. Ceramah digunakan untuk menyampaikan materi, dialog untuk memberi kesempatan bertanya kepada peserta kegiatan dan memberikan jawaban jika kurang jelas atau ada permasalahan. Penugasan dimaksudkan sebagai langkah terusan dari teori yang telah diterima para peserta kegiatan menuju praktik menulis. Dalam praktik itu tugas yang harus dikerjakan para santri adalah menulis karya 
sebagaimana yang dikaji dalam bahasan itu. Jika dalam pertemuan membahas artikel, maka tugas yang diberikan adalah tentang artikel, jika cerpen tugas yang diberikan tentang cerpen, jika puisi maka tugas yang diberikan juga tentang puisi dan sebagainya. Tugas yang diberikan dalam pertemuan hari ini dikumpulkan pada pertemuan berikutnya, yaitu minggu depan. ${ }^{15}$

Dengan pemberian tugas kepada masing-masing peserta tersebut dapat memberikan beberapa manfaat, khususnya bagi peserta yaitu pertama untuk melibatkan langsung para peserta dengan kajian yang yang telah dibahas. Dengan penugasan membuat karya tersebut minimal seseorang akan berusaha menggali informasi tentang tugas itu secara lebih dalam sebagai bekal pengerjaan tugas.

Kedua untuk mengetahui sejauh mana para peserta mempunyai bakat dan kecenderungan terhadap materi kajian. Atas dasar kecenderungan tersebut akan lebih mempermudah pemandu untuk membimbing dan mengarahkan secara maksimal, apakah peserta ini lebih cocok di bidang sastra, di bidang wacana atau di bidang yang lain.

Untuk menjaga dan memperkuat motivasi yang ada dalam diri peserta, secara berkala pelatihan diisi dengan kajian "Management Diri". Dari kajian ini pengasuh dengan segala teknik retorikanya berusaha memupuk semangat para santri agar bisa terus semangat dalam berilmu dan berkarya, memadukan antara keilmuan dan etos kerja.

b. Mendatangkan Tokoh-tokoh yang telah Sukses Menulis

Untuk memenuhi kebutuhan kebutuhan para santri dalam kekayaan pengalaman dan memperkuat motivasi tersebut K.H. Zainal Arifin Thoha berusaha mendatangkan beberapa relasi dan temannya yang telah sukses dalam dunia kepenulisan untuk berdiskusi dan berdialog bersama para santrinya. Biasnya dialog ini diadakan pada tiap malam Minggu, disamping dialog lain yang sifatnya tak terencana. Yang dimaksud dengan dialog tidak terencana adalah kegiatan yang sifatnya mendadak dengan mengumpulkan para santri di ruang aula untuk dipertemukan dengan para tamu yang kebetulan berkunjung ke rumah pengasuh. Pengasuh memang sengaja meminta para tamu, khususnya yang telah lama menekuni kehidupan menulis untuk berdialog dan tukar pengalaman dengan para santri.

Para tamu yang didatangkan adalah para teman dan relasi pengasuh, khususnya yang tinggal di Yogyakarta. Diantara yang pernah didatangkan ke pesantren tersebut

15 Wawancara dengan KH. Zainal Arifin Thoha, 10 Maret 2007. 
adalah D. Zawawi Imron, penyair asal Madura yang terkenal dengan julukan Celurit Emasnya yang didatangkan pada bulan Januari, Mei dan Juli 2004, Kuswaedi Syafei, penyair dan essais asal Madura yang seringkali mengangkat dimensi tasawuf dalam banyak karyanya, yang hadir di pesantren pada tiap malam Jum'at bersamaan dengan pelaksanaan kegiatan rutinan pembacaan kitab Maulidi al Barzanji dan diskusi serta dialog bebas dengan para santri, Raudal Tanjung Banua, penulis cerpen asal Sumatera yang telah merantau di berbagai kota, hingga akhirnya tinggal di Yogyakarta yang didatangkan pada bulan Februari dan April 2004, Jhoni Ariadinata, cerpenis asal Majalengka yang pernah tinggal di jalanan dalam proses menulisnya yang didatangkan pada bulan Januari, Maret, April dan Agustus 2004, Abdul Wahid B.S, penyair asal Jawa Timur yang telah banyak menerbitkan antologi puisi bercorak cinta yang didatangkan pada bulan Februari dan Juni 2004, Evi Idawati, penyair, artis film dan cerpenis asal Demak yang didatangkan pada bulan Maret 2004, Matori A. Elwa yang didatangkan pada bulan Agustus 2004, Djamal D. Rahman yang didatangkan bulan September 2004, Haidir Bujung yang didatangkan pada bulan Agustus 2005 dan tokoh lain yang kebetulan mampir ke rumah pengasuh, pernah kenal ataupun kawan lama yang dahulunya pernah menjalani prosesnya dalam menulis bersama K.H Zainal Arifin Thoha.

Dengan media pengenalan para tokoh seperti ini paling tidak bisa mendatangkan beberapa manfaat dan keuntungan bagi para santri, pertama para santri mendapatkan banyak motivasi karena mendengar kisah dan berdialog langsung dengan berbagai karakter orang dan proses yang berbeda-beda serta kiat mencapai kesuksesan yang berbeda pula. Kedua para santri dapat memperbanyak relasi, khususnya dengan para tokoh dan penulis yang hal itu tidak mudah didapat lewat jalur lain seperti seminarseminar yang waktu mereka sangat dibatasi karena harus berinteraksi dengan orang banyak. Dengan pertemuan ini bisa ditindaklanjuti dan disambung dengan silatur rahmi jika memang dianggap perlu oleh masing-masing santri.

\section{c. Membangun Iklim Penulis}

Langkah lain yang digunakan oleh pihak pesantren di dalam memupuk motivasi dan semangat para santri dalam menulis adalah membangun "Iklim Penulis". Yang dimaksudkan dengan membangun iklim penulis adalah membangun alam pesantren yang mendukung para santri di dalam menulis. Pembangunan iklim itu bisa dibentuk dengan menciptakan alam persaingan menulis (termasuk juga untuk pengasuh), mengadakan kajian-kajian yang banyak berorientasi kepada kepenulisan, menggalakkan budaya membaca dan langkah lain yang sejenis. 
Sebagai sarana publikasi karya bagi yang telah berhasil masuk ke media massa, disediakanlah sebuah majalah dinding tempat sosialisasi karya atau tulisan yang telah dimuat di media massa. Dengan model seperti ini, tentunya bagi yang tidak pernah dimuat sama sekali akan merasa malu dan sungkan, baik kepada pengasuh atau sesama teman. Diharapkan dengan rasa sungkan tersebut para santri akan menjadi bertambah gigih di dalam berusaha mencapai keberhasilan menulis.

Mading atau tempat publikasi karya yang disediakan oleh pihak pesantren tersebut oleh kalangan santri sering disebut dengan istilah "Publishing". Publishing tersebut sengaja ditempatkan pada tempat yang mudah dilihat, baik oleh tamu maupun para santri. Lewat Mading ini para santri dapat menunjukkan eksistensinya, baik itu dalam pandangan pengasuh, para tamu ataupun santri lain.

Langkah lain yang diterapkan oleh pihak pesantren dalam rangka mendukung terbentuknya iklim penulis dan memencing bertumbuhkembangnya motivasi dalam diri para santri adalah dengan menugaskan kepada para santri senior untuk melakukan bimbingan dan pendampingan lanjutan.

Santri senior yang diberi tugas melakukan pendampingan tersebut dipilih lansung oleh pengasuh berdasarkan beberapa pertimbangan, salah satu diantaranya adalah kemapanannya dalam mengambil prediksi dan langkah menembus media massa. Dengan kata lain seringnya dimuat dalam berbagai media massa. Disamping itu juga kemampuan dan kecakapannya dalam berdiskusi maupun berinteraksi dengan pihak lain yang bisa dilihat dalam berbagai kajian ataupun diskusi yang dilaksanakan di pesantren tersebut.

Cara yang biasanya ditempuh oleh para pendamping untuk lebih mempercepat proses kepenulisan adalah dengan menunjukkan literatur atau bacaan tertentu yang dianggap paling efektif jika dibaca sebagai bahan dan wacana menulis. Bisa juga dengan memberi tugas membuat kliping dari berbagai media massa, kemudian supaya dibaca dan dipelajari.

Masing-masing santri senior yang mempunyai tugas mendampingi mempunyai langkah yang berbeda-beda dalam memprediksi termuatnya karya. Dengan sistem inilah pengasuh bermaksud agar di antara para santri seniorpun timbul persaingan menulis, bahkan dari pengasuh sendiri. Dengan model seperti inilah diharapkan alam persaingan dan kompetisi di dalam kebaikan akan tercipta.

\section{Pengenalan Teori Praktis dalam Pembelajaran Jurnalistik Praktis}

Menulis merupakan aktifitas sangat erat hubungannya dengan praktik, karena menulis sendiri adalah suatu bentuk ketrampilan, hanya saja banyak berhubungan 
dengan fikiran. Karena dalam menulis terdapat berbagai model dan jenis karya, tentunya secara umum masing-masing karya tersebut memiliki ciri-ciri, karakter dan bentuk yang berbeda-beda. Untuk mengetahui perbedaannya seseorang haruslah mengetahui teori tentang ciri-ciri, karakter ataupun bentuk dari masing-masing karya itu. Singkatnya dalam menulis meskipun banyak memerlukan praktik, tetapi teori tetap diperlukan.

Pihak pesantren berpendapat bahwa unsur terbesar yang meski dimiliki oleh seorang penulis, terutama penulis pemula adalah praktik. Terkadang timbunan teori yang banyak, diikuti berbagai batasan ketat malah membuat para penulis, terutama pemula menjadi berat dan kesulitan untuk memulai, meskipun begitu bukan berarti tidak perlu teori sama sekali. Untuk mengatasi permasalahan itu, pihak pesantren mengambil alternatif dengan mengenalkan teori-teori yang sifatnya praktis (bersinggungan langsung dengan praktik), dan sangat signifikan dalam menulis. K.H. Zainal Arifin Thoha dalam pelatihannya menyampaikan teori-teori dan konsep-konsep yang didapati dari rintisan pengalamannya dalam menulis. Bahkan teori-teori itu kini telah dituliskannya dalam bentuk buku yang berorientasi motivasi untuk menulis. Buku tersebut berjudul Dengan Menulis Aku Ada yang diterbitkan oleh penerbit "Kutub" dengan tahun terbit 2005.

\section{Praktik Menulis dan Aktualisasi Karya}

Menulis tidak bisa dikatakan mudah karena sasaran yang dituju adalah khalayak, yang dalam media-media massa diwakili oleh tim redakturnya. Untuk bisa memenuhi keinginan para redaktur, kita harus bisa membaca moment, selera dan visi-misi dari masing-masing media massa yang dituju. Untuk mengerti hal itu harus ditempuh dengan mencoba dan belajar, baik itu dari pengalaman, literaturliteratur ataupun orang lain yang biasa terjun di dunia tulis menulis.

Untuk bisa membaca visi-misi dan selera dari masing-masing media massa tidaklah cukup dengan belajar teori saja, dengan mengabaikan praktik dan mencoba. Pihak pesantren berpendapat bahwa mencoba membuat dan mengirimkan karya kepada tim-tim redaksi berbagai penerbit secara berulang-ulang diikuti pengamatan dipandang lebih efektif daripada menumpuk teori dahulu, baru dilakukan praktik. Kadang-kadang teori yang banyak dengan aturan-aturan yang ketat bisa membuat penulis pemula menjadi bingung dan merasa terbuntu oleh berbagai aturan yang ada. Jadi lebih baik praktik dahulu, pengembangan teori dan wawasan lain bisa di cari sambil berproses. 
Mengenai permasalahan ini K. H. Zainal Arifin Thoha sering menyampaikan pesannya yang berbentuk idiom yang berbunyi; Lebih baik berbuat meski sedikit, daripada berpikir banyak tetapi tidak berbuat. Atas dasar itulah praktik menjadi komponen pokok yang diterapkan didalam pembelajaran menulis.

Praktek menulis dan aktualisasi karya merupakan salah satu strategi yang ditempuh oleh pihak pesantren dalam usahanya mempercepat proses kepenulisan. Secara khusus praktik menulis dilaksanakan melalui penugasan-penugasan yang diberikan pada setiap akhir pertemuan pelatihan. Masing-masing peserta harus menyerahkan karya sesuai dengan tema atau bahasan yang dikaji di dalam pelatihan dan diserahkan pada pertemuan berikutnya. Bila pembahasan yang dilakukan adalah tentang cerpen, maka untuk para peserta harus pula membuat cerpen dengan ciri khas sesuai seleradan kecenderungan masing-masing dan dikumpulkan pada pertemuan berikutnya.

Hasil dari tugas tersebut akan diteliti dan diseleksi oleh pembimbing, kemudian diberikan pengarahan-pengarahan khusus sesuai keperluan atau sebagai sarana untuk mencari permasalahan dan kesulitan yang dihadapi masing-masing, kadang disarankan dikirimkan ke media massa bagi yang dianggap sudah layak. Biasanya pengarahan dilanjutkan melalui penunjukan wacana yang meski dibaca dan penugasan kepada para santri senior untuk melakukan pembimbinganpembimbingan yang biasa disebut dengan istilah "pendampingan".

Melalui strategi praktik dan pencarian tersebut diharapkan para santri dapat langsung berproses dan mencari sendiri apa yang dia butuhkan. Itu dianggap lebih efektif karena dengan mencari sendiri, didorong dengan arahan dan motiasi akan menimbulkan kesan yang lebih kuat dan mendalam dibanding dengan doktrinasi dan penyampaian secara ceramah. Apalagi praktik yang melibatkan seseorang di dalam berproses, beserta pahit manis dan senang susahnya akan lebih memancing banyak inspirasi, khususnya di dunia sastra.

Untuk mendukung hal-hal tersebut pesantren sengaja membikin iklim penulis, yaitu menciptakan iklim persaingan menulis di dalam komunitas pesantren. Hal ini telah dibahas di depan, yaitu pada bahasan Motivasi Sebagai Dasar Utama Pengemangan Potensi Kepenulisan.

\section{E. Hasil dan Manfaat Kegiatan Jurnalistik Praktis}

Jurnalistik Praktis merupakan kegiatan yang dilaksanakan di Pesantren Mahasiswa Hasyim Asy'ari dengan tujuan pokok untuk mengembangkan potensi 
santri di bidang kepenulisan. Dalam pencapaian suatu tujuan pastilah akan didapati hasil, terlepas dari maksimal tidaknya pencapaian hasil itu. Hasil adalah sesuatu yang didapat dari sebuah tujuan (pencapaian). Dari penelitian di pesantren tersebut dapat disimpulkan hasil yang dicapai dalam pelaksanaan kegiatan tersebut.

Tujuan pokok pelatihan tersebut adalah untuk membentuk peserta pelatihan (para santri) menjadi penulis. Keberhasilan tujuan di sini dapat distandarkan dengan mampunya menembus media massa dan memprediksi keinginan redaktur. Di depan telah dibahas bahwa di dalam membaca kehendak para redaktur diperlukan beberapa proses, yang diantaranya adalah dengan sering mencoba menulis, mengirim dan secara cermat menganalisis karakter yang dikehendaki masing-masing media.

Dalam usahanya membantu para santri menempuh proses penulisan, pengasuh menugaskan para santri senior untuk membiming santri baru, biasanya bimbingan dilakukan berdasarkan pengalaman yang dimiliki masing-masing pembimbing di dalam menembus media massa. Untuk langkah ke dalam, pihak peantren bisa dikatakan telah "berhasil", terbukti dengan para santri yang mampu menembus atau dimuat di berbagai media massa, baik itu yang berskala lokal mapun nasional.

Persentase santri yang telah mampu menembus media massa sebagaimana data di depan, yaitu sekitar 70\% dari keseluruhan santri yang berjumlah 70 dengan perincian 20\% tingkat nasional, 50\% tingkat lokal dan 30\% belum dimuat. Semua yang belum dimuat adalah santri baru yang baru mengawali proses menulis.

Sedangkan untuk yang ke luar bisa dikatakan belum sukses, karena disamping belum kelihatan hasil nyata berupa tulisan dari para peserta diklat, juga tehentinya pelatihan karena tidak ada lagi peserta yang mendaftar. Ini disebabkan kurangnya persiapan dan koordinasi dari masing-masing tim, sehingga pelaksanaan pelatihan menjadi kurang matang dan tidak berkelanjutan. Namun, dalam melaksanakan tujuan pesantren pelatihan ini bisa dikatakan sudah berhasil, karena sasaran utama kegiatan di pesantren tersebut adalah untuk para santri, dan para santri sebagian besar telah mampu memasukkan tulisannya ke berbagai media massa..

Dari pelatihan Jurnalistik Praktis dan kegiatan lain yang mendukungnya, tentunya tidak hanya bemanfaat melatih para santri di bidang kepenulisan saja, tetapi bisa juga melahirkan manfaat-manfaat lain yang bisa jadi lebih luas jangkauannya. Pada pembahasan dan analisa inilah akan dikelompokkan manfaatmanfaat yang bisa timbul dari pelaksanaan kegiatan tersebut.

Manfaat yang bisa didapat oleh para santri dari pelaksanaan pelatihan tersebut ada dua kategori. Yang pertama adalah manfaat yang sifatnya "langsung" dan yang 
kedua yang sifatnya "tidak langsung". Manfaat langsung di sini diartikan sebagai manfaat yang yang diperoleh santri berdasarkan kedudukannya sebagai santri di pesantren tersebut (ke dalam), dan yang tidak langsung adalah yang menyangkut para santri dalam sisi lain, baik itu sebagai mahasiswa atau yang lainnya (ke luar).

Berkaitan dengan permasalahan itu, ketua pesantren menyatakan bahwa dengan adanya kegiatan Jurnalistik Praktis secara umum dapat memberikan pengaruh positif bagi para santri. Di antara pengaruh positif tersebut adalah terpupuknya etos kerja, kemandirian dan rasa percaya diri di dalam pertukaran wacana, baik itu di kampus, berbagai diskusi maupun dalam berorganisasi karena kebiasaan yang telah terbangun di dalam komunitas pesantren.

Penuturan tersebut dapat menjadi bahan rujukan untuk mengambil kesimpulan terhadap hasil dan manfaat dari Jurnalistik Praktis, khususnya bagi para santri. Jadi dampak positif yang didapat oleh para santri bukan hanya berlaku dalam kedudukannya sebagai santri di pesantren atau kedudukannya sebagai calon penulis, tetapi juga sebagai pendukung proses perkuliahannya di kampus.

Manfaat yang yang paling jelas adalah kebiasaan membaca yang terpupuk dalam diri para santri, dengan kebiasaan tersebut secara tidak langsung akan lebih mempertajam pemahaman dan analisisnya di dalam memahami ungkapan literatur. Dari sisi lain kebiasaan berdiskusi dan mengapresiasikan karya bisa mendukung para santri di dalam menyampaikan berbagai argumen dan mempertahankannya sebagai hal yang selalu dibutuhkan di dalam setiap diskusi dan interaksi di kampus. Dengan bekal tersebut para santri menjadi lebih percaya diri di dalam menghadapi siapa pun, karena telah terbekali berbagai wawasan dan nilai lebih dari temanteman lain.

\section{F. Jurnalistik Praktis sebagai Kurikulum Semi Otonom Pesantren}

Berdasarkan pendeskripsian dan uraian pada bahasan sebelumnya, yaitu mengenai Jurnalistik Praktis sebagai media pengembangan potensi kepenulisan di Pesantren Mahasiswa Hasyim Asy’ari, dapat diambil suatu kesimpulan bahwa pada dasarnya pelatihan tersebut dapat dikatakan berhasil. Hasil tersebut bisa dicerminkan dengan mulai muncul dan dimuatnya tulisan para santri di pesantren tersebut di berbagai media massa, yaitu dengan prosentase $70 \%$, tingkat lokal $50 \%$, nasional $20 \%$ dan yang belum 30\%.

Dari visi-misi yang dibangun di pesantren tersebut, dapat difahami bahwa pada dasarnya Jurnalistik Praktis sebagai kurikulum semi otonom pesantren 
(kurikulum pesantren yang berdiri sendiri dan terpisah dari jadwal pengajian) merupakan kegiatan inti yang mencerminkan tujuan didirikannya pesantren tersebut. Oleh karena itu, untuk mendukungnya tidak bisa lepas dari kajian-kajian lain yang masuk dalam kurikulum resmi pesantren.

Contohnya pembentukan iklim penulis (iklim persaingan menulis) di pesantren, pelaksanaan kajian editorial, lesehan sastra dan budaya, diskusi-diskusi dan kegiatan lain yang berorientasi ke arah pengembangan kompetensi kepenulisan. Begitu juga dengan didirikannya penerbit "Kutub", dan digerakannya para santri dalam biang pemasarannya (asongan) sebagai sarana pendukung kebutuhan finansial juga tidak lepas dari orientasi kepenulisan itu sendiri.

Visi-misi yang dituju pesantren adalah mencetak kader-kader ilmuwan muslim yang taat, berkepedulian tinggi, dan mampu mengikuti perkembangan zaman. Jika para hartawan yang menyumbangkan hartanya kepada masyarakat sebagai wujud kepeduliannya, maka seorang ilmuwan menuangkan rasa pedulinya melalui sumbangan keilmuannya. Untuk bisa melakukannya diperlukan kemampuan, cara dan strategi khusus yang membutuhkan keseriusan dan banyak latihan. Keilmuan bisa didarmakan melalui tulisan di buku-buku, majalah-majalah, buletin-buletin ataupun media massa-media massa.

Langkah yang ditempuh untuk membekali para santri agar mampu mengikuti perkembangan zaman melalui keilmuan yang dimilikinya adalah dengan membekali mereka dengan kemampuan menulis. Wahana yang digunakan untuk pembekalan tersebut adalah kegiatan Jurnalistik Praktis, yang dalam pelaksanaanya selalu didukung dengan kegiatan-kegiatan lain di pesantren tersebut.

Dalam rangka proses menuju kompetensi menulis (pihak pesantren menyebut sebagai “Tujuan jangka panjang”), pihak pesantren memberikan kesempatan kepada para santri untuk bekerja sebagai tim pemasaran penerbit "Kutub" dalam bentuk berjualan asongan. Kegiatan asongan tersebut oleh pihak pesantren disebut sebagai "Tujuan jangka pendek", yaitu untuk memperoleh hasil yang digunakan dalam mencukupi kebutuhan finansial. Di samping itu, juga dirintis peternakan ayam yang akan difungsikan sebagai sarana pemenuhan kebutuhan finansial santri.

\section{G. Penutup}

Berdasarkan uraian di atas, dapat dilihat bahwa pada dasarnya apa yang dilakukan oleh pihak pesantren tersebut adalah salah satu alternatif yang bisa dikatakan unik untuk dunia pesantren. Pesantren tersebut telah berusaha 
mengintegrasikan antara vocational dengan pengembangan keilmuan. Vocational dapat dilihat dari kegiatan asongan (menjual buku) dan kegiatan menulis itu sendiri. Menulis dalam hal ini dapat di masukkan ke dalam vocational dan pengembangan keilmuan, karena pada dasarnya kedua hal tersebut dapat dicapai dalam dunia kepenulisan.

Menulis sebagai sebuah ketrampilan, jika dilakukan dengan maksimal dan telah mencapai kemapanan (dalam arti cukup bisa membaca selera redaktur dan masyarakat umum) akan mendapatkan konsekwensi finansial, yaitu berupa honor. Untuk penulis buku bisa melalui royalti (pembayaran tidak langsung) ataupun langsung. Untuk honor yang didapat, khususnya media-media massa yang jangkauannya luas atau nasional, juga relatif besar disbanding yang lokal. Misalnya haarian Kompas, satu tema opini yang termuat bisa mendapatkan honor sekitar empat ratus sampai delapan ratus ribu rupiah, Jawa Pos sekitar dua ratus ribu rupiah, Kedaulatan Rakyat sekitar seratus ribu rupiah.

Yang paling penting di sini adalah nilai positif yang dapat dipetik, khususnya kebiasaan membaca yang akan terpupuk jika seseorang gemar menulis. Bagi orangorang yang terlibat di dalam dunia pendidikan dan memerlukan banyak wacana tentunya akan lebih peka dalam memahami maksud yang terkandung di dalam berbagai literatur sebagai efek dari sebuah kebiasaan membaca.

\section{DAFTAR PUSTAKA}

Ahmad, Kamaruzzaman Bustaman. 2002. Islam Historis: Dinamika Studi Islam di Indonesia. Yogyakarta: Galang Press.

Asy’ari, Zubaidi Habibullah. 1996. Moralitas Pesantren. Yogyakarta: LKPSM.

Baidhawy, Zakiyuddin. 2005. Pendidikan Agama Berwawasan Multikultural. Jakarta: Erlangga.

Bashori, Khoiruddin. 2003. Problem Psikologis Kaum Santri: Risiko Insekuritas Kelekatan.

Brunessen, Martin Van. 1999. Kitab Kuning Pesantren dan Tarikat: Tradisi-Tradisi Islam di Indonesia. Bandung: Mizan.

Dhofier, Zamakhsyari. 1994. Tradisi Pesantren: Studi tentang Pandangan Hidup Kiai. Jakarta: LP3ES.

Falakh, M. Fajrul. 1999. Pesantren Masa Depan: Wacana Pemberdayaan dan Transformasi Pesantren. Bandung: Pustaka Hidayah. 
Madjid, Nurcholis. 1999. Bilik-bilik Pesantren: Sebuah Potret Perjalanan. (Jakarta: Paramadina.

Majalah Pustaka Promo. 2007. "Lembaga Kajian Kutub Yogyakarta: Mandiri dengan Menulis”, edisi 07 Maret.

Mastuhu. 1994. Dinamika Sistem Pendidikan Pesantren. Jakarta: INIS.

Mas'ud, Abdurrahman. 2000. "Pesantren dan Walisongo: Sebuah Interaksi dalam Dunia Pendidikan” dalam M. Darori Amin (ed.), Islam dan Kebudayaan Jawa. Yogyakarta: Gama Media.

Siraj, Said Agil et.al. 1999. Pesantren Masa Depan. Bandung: Pustaka Hidayah.

Wahyoetomo, Ar. 1990. Perguruan Tinggi Pesantren Alternatif Masa Depan. Jakarta: Gema Indonesia Press.

Wawancara dengan Ach. Mukhlis AR, 25 April 2007.

Wawancara dengan KH. Zainal Arifin Thoha, 10 Maret 2007.

Wawancara dengan Muhammadun AS, 12 April 2007.

Wawancara dengan Muhammadun AS, 12 April 2007.

Wawancara dengan Muhammadun AS, 12 April 2007.

Zulkifli. 2002. Sufi Pesantren. Yogyakarta: LKIS. 